Original Research Paper

\title{
Analysis Validation of Learning Media Quantum Phenomenon
}

\author{
Baiq Uswatul Khasanah"1,, Aris Doyan', Gunawan', Susilawati' ${ }^{1}$, Kartini', Syamsul \\ Hakim $^{1}$, Lalu Muliyadi ${ }^{1}$ \\ ${ }^{1}$ Master of Science Education Program, University of Mataram, Lombok, West Nusa Tenggara, Indonesia
}

\author{
Article history \\ Received: May 27 2019 \\ Revised: June $20^{\text {th }} 2019$ \\ Accepted: July $10^{\text {th }} 2019$ \\ *Baiq Uswatul Khasanah: \\ Master of Science \\ Education Program, \\ University of Mataram, \\ Lombok, West Nusa \\ Tenggara, Indonesia; \\ Email: \\ uswatulbaiq@gmail.com
}

\begin{abstract}
This study aims to produce learning media in high school grade XII science quantum phenomenon material. This research is a development research that uses the research and development model of Borg and Gall with ten stages, but in this study only followed until the fifth step. Data from development research results in the form of a percentage of validity of learning media from the validation sheet in the form of responses and suggestions obtained from the test results by material experts and media experts. This learning media is supported by syllabus, learning implementation plans, and student worksheets as well as instruments for understanding students' concepts and critical thinking skills. The focus of this research is the validity test by material experts, media experts on the media developed. The results of the learning media validation from the test subjects were declared appropriate for use.
\end{abstract}

Keywords: Learning Media; Quantum Phenomenon; Validation

\section{Introduction}

Technological developments in the world of education require teachers to play an active role in the learning process. To make it easier for teachers to deliver learning material, concrete steps are needed so that students easily accept the material presented. In realizing this, several steps need to be taken, for example designing teaching materials in the form of technology such as multimedia. In the world of education facilities and educational resources are needed that can facilitate the implementation of effective teaching and learning processes (Wahyudin, 2010).

Previously many media have been developed to support the learning process. In general, the benefits that can be obtained through the use of interactive multimedia is that the learning process can be carried out more interesting, more interactive, the amount of teaching time can be reduced, the quality of student learning can be improved and the teaching and learning process can be done anytime, and can improve students' reasoning abilities (Heinich 1996 in Sutarno, 2011). The results of the research by Rante et al. (2013) state that the level of implementation of learning by using multimedia-based audio-video experiments and supporting devices as a whole is carried out entirely so that it can be said to be practical and effective. In line with the results of the study from Alimah (2012), it was concluded that the learning media developed were suitable for use as an alternative learning resource that could be used in the learning process of animal embryo-genesis.

Practical and effective media design must go through a validation process. Before being used for product usage testing, it is necessary to test the validity of learning media. Learning media validation is intended to ensure that learning media that have been made are appropriate to use and can measure what they want to measure. Validity shows the degree of accuracy between data that actually occurs in objects with data collected by researchers (Sugiyono, 2017: 125).

Learning Media in the material quantum phenomenon is an interactive learning media that contains text, video, audio and images and is integrated with phet simulation which can be used to study independently or study with the teacher. Nurhayati et al (2014) research using PhET simulation makes the lesson more interesting because students can use the PhET software 
animation media can also provide learning experiences as well as play. Research conducted by Khairunnisak (2018) PhET makes it easier for teachers and students in the learning process, so that it can foster motivation towards students and improve students' conceptual understanding.

Based on the background above, there will be a validation analysis of learning media that has been developed in the material of the XII class science high school quantum phenomenon. Learning media as an additional variation of media that can be used in the learning process in the classroom. The purpose of developing the media is to support Teaching and Learning activities in Bodok Attohiriyah High School, especially for physics class XII IPA subjects.

\section{Method}

In developing this learning media, it is carried out with stages of research and development in education, in accordance with the steps set by Borg and Gall. The stages of developing this learning media are:

\section{Information Collection}

Information collection is done through the study of literature relating to the problems studied in order to obtain theoretical foundations from various sources and to find out previous research that is relevant to the research problems. In addition to literature studies, at this stage researchers also conduct field studies with observation techniques to determine the actual conditions in the field related to the use of learning media.

\section{Planning}

Planning is prepared based on literature studies that have been done before. Based on the literature study of the products produced in electronic form, hardware and software are needed in the manufacture. In addition, the product will also be applied in learning so the content of the material must be in accordance with the demands of the curriculum so that it is necessary to study the learning device. The assessment process includes the determination of material specifications, analysis of core competencies (CC)/basic competencies (BC) based on learning syllabus and analysis of learning resources. Based on some of this information, a Learning Implementation Plan (LIP) was prepared which was also adjusted to the think pair share learning model and the preparation of the expected learning outcomes instruments.
Based on the results of the Enis et al (2012) study after applying the cooperative learning model of think pair share on the subject of optical devices showed collaboration and student learning outcomes had increased. Besides that the application of the think pair share learning model can increase motivation and learning achievement (Hetika et al, 2017).

\section{Product Draft Development}

At this stage the researcher makes or designs product development, namely the learning media of quantum phenomena. There are several steps taken to produce this product. These steps are outlined as follows (Darmawan, 2015): (a) Determine the flow of teaching material, (b) Determine the flow chart (a comprehensive description of the program flow made with certain symbols), (c) make a Story Board (guidelines for programmers and animators in realizing the program plan into program language) and animation), (d) collecting graphic materials, functions to clarify information, beautify the appearance and make the program more alive with various color combinations and objects can be photos, cartoons, image illustrations, photo engineering, and text use, (e) collecting animation material, (f) Programming (this stage combines various graphic, animated, and text materials arranged according to the flow that matches the flow chart using software), (g) Finishing, mastery (final stage in programming).

\section{Design Validation}

Design validation is an assessment of the feasibility of the results of the design of quantum learning media by a team of experts (media experts, material experts) and practitioners. Criteria experts here are people who are competent in the field of education, especially multimedia learning, learning technology and have a background in the field of physics or physics education. As for the criteria for practitioners here, namely people who have experienced using similar products, they are physics teachers in high schools.

\section{Product Revision}

The Idyllic revision is based on data obtained from the results of design validation. Revision activities are in the form of improvements to criticism, input or suggestions obtained based on the assessment of expert teams and practitioners. The discussion in this development is limited to product revisions based on suggestions and input from material experts and media experts. 
Data obtained from the results of validation by media experts and material experts were analyzed using component percentages based on the Likert scale in Table 1.

Table 1: Questionnaire Instrument Scoring

\begin{tabular}{ll}
\hline Answer & Score \\
\hline Very Good & 5 \\
Good & 4 \\
Enough & 3 \\
Less & 2 \\
Very Less & 1 \\
\hline
\end{tabular}

The score is then calculated to determine the percentage of components with the following equation:

$$
P_{(k)}=\frac{s}{N} \times 100 \%
$$

Information:

$\mathrm{P}(\mathrm{k})=$ Percentage of components

$\mathrm{S}=$ Number of score components of research results

$\mathrm{N}=$ Maximum score

The percentage that has been obtained is then transformed into intervals as in Table 2.

Table 2: Percentage ranges and qualitative criteria

\begin{tabular}{ll}
\hline Percentage of & Criteria \\
\hline $85 \%-100 \%$ & Very Good \\
$69 \%-84 \%$ & Good \\
$53 \%-68 \%$ & Enough \\
$37 \%-52 \%$ & Less \\
$20-36 \%$ & Very Less \\
\hline
\end{tabular}

(Source: Sugiyono, 2017)

In this study if the validator provides a minimum of sufficient value, the product is suitable for use in learning.

\section{Result and Discussion}

As explained earlier, the stages in developing the quantum phenomenon learning media use the stages of Borg and Gall. In the process of gathering information, observations have been carried out in several schools and schools chosen by the researchers: Attohiriyah Bodak High School, Praya District, Central Lombok. Researchers choose this school based on the results of interviews with physics subject teachers and see the characteristics of students during the learning process.

The results of the analysis of students that on average consider physics lessons difficult to understand and many calculations. In addition to observations, researchers also conduct literature studies and find out research results that are relevant to abstract material physics. Researchers also found that multimedia-based learning media were still minimal used by teachers in this school. Therefore researchers decided to develop learning media on quantum phenomenon material based on the characteristics of students and abstract material physics.

During the planning and development stages of the product draft, researchers collected media materials from various sources adapted to the 2013 curriculum. Next the researcher created a flow chart or media flow that is complete with storyboards or sketches of images that tell a series of storylines.

The stages of validation are carried out by material experts and media experts. The two experts are lecturers in the Mataram University Natural Sciences education master's program, totaling three people.

Validation results in the form of data analyzed using the percentage of components and then taken the average score of each validator. There are three aspects assessed by material experts, namely: content, method, language, with each aspect having a description with 24 number of statements. The results of the material expert validation are shown (Table 3). Critics or suggestions from material experts (Table 4).

Table 3: Presentation of Material Expert Test Results

\begin{tabular}{llll}
\hline Validator & Feasibility & Criteria & Level of Validity \\
\hline - Media Expert 1 & $-85 \%$ & - Very Good & - Very Valid \\
- Media Expert 2 & $-79 \%$ & - Good & - Valid \\
- Media Expert 3 & $-80 \%$ & - Good & - Valid \\
- Average Score & $-78 \%$ & - Good & $\begin{array}{l}- \text { Valid and feasible with revisions as } \\
\text { recommended }\end{array}$ \\
\hline
\end{tabular}

Table 4: Material Expert Test Results

\begin{tabular}{lll}
\hline Validator & Critics/Suggestion \\
\hline Media Expert & - & Give a description of each image and source written in parentheses. \\
& - & For student worksheets include interesting images related to the material to provide \\
& motivation to students. \\
& - & The question indicator adjusts from the fields C1 to C6. \\
\hline
\end{tabular}




\begin{tabular}{ll}
\hline Validator & Critics/Suggestion \\
\hline & For learning implementation plans, don't copy and paste the words and distinguish the \\
& role of the teacher from the role of the students. \\
- & The layout of the answer choices is not neat. \\
- & Mention PhET in learning implementation plans. \\
- & Adjust between indicators and learning goals. \\
\hline
\end{tabular}

Table 3 shows the results of the trial of material experts that quantum phenomenon learning media is feasible. These results can be seen from the average overall score of $78 \%$ with good criteria. The percentage of feasibility shows that the quantum phenomenon learning media is feasible to use with revisions according to the advice of the material experts presented in table 4 .
In terms of products, quantum phenomenon learning media is validated by media experts with five aspects, namely: language, illustration, completeness, physical/display, software engineering and audio visual, with each aspect having a description with 19 number of statements. The results of media expert validation are shown in (Table 5) while critics or suggestions from media experts (Table 6).

Table 5: Presentation of Test Results for Media Experts

\begin{tabular}{llll}
\hline Validator & Critics & Criteria & Level of Validity \\
\hline - Media Expert 1 & $-79 \%$ & - Good & - Valid \\
- Media Expert 2 & -77 & - Goo & - Valid \\
- Media Expert 3 & $-76 \%$ & - Good & - Valid \\
- Average Score & $-77 \%$ & - Good & - Valid and feasible with revisions as recommended \\
\hline
\end{tabular}

Table 6: Test Results of Media Experts

\begin{tabular}{lll}
\hline Validator & Critics/Suggestion \\
\hline Material Expert & - & Letters must be easier to read / font / large letters. \\
& - & Colors should make it easier for the reader \\
& - & The combination of colors must clarify the content or content \\
& - & The background color should be replaced because it is too contrasted \\
\hline
\end{tabular}

Table 5 shows that the percentage results from media experts that quantum phenomenon learning media is feasible. These results can be seen from the overall percentage of $77 \%$. The percentage of feasibility shows that quantum phenomenon learning media is valid and feasible to use with revisions according to the suggestions presented in Table 5. This is done so that learning media is truly feasible if it is to be used in a widescale test.

Quantum phenomenon learning media is learning media developed in order to add media variation in the learning process that is adjusted to the 2013 curriculum. This media was developed based on the results of observations and literature studies related to theory and relevant research. Besides that the character of students is also a consideration in developing the learning media. This learning media is expected to contribute to the learning process for both teachers and students. The main objective of this development is to see an increase in understanding of concepts and critical thinking skills of students after using quantum phenomenon learning media.
Learning media developed have been validated by material experts and media experts. Validation results show that learning media of quantum phenomena are feasible. The results of the overall material expert validation were $78 \%$. These results show that in terms of material learning media are categorized as appropriate to use. The results of the overall media expert validation obtained an average score of $77 \%$. These results indicate that the learning media includes a decent category with good criteria.

The feasibility of the quantum phenomenon learning media that is developed must still be revised according to the advice of material experts and media experts. Good media is media that meets several aspects. There are several aspects to assess or evaluate multimedia learning, namely aspects of subject matter, auxiliary information, affective considerations, interfaces, navigation, pedagogy, and robustness so that the media can be said to be feasible to use (Winarno, 2009: 74). 


\section{Conclusion}

Based on the description above, it can be concluded that the learning media of quantum phenomena is feasible to use with a percentage of $78 \%$ according to material experts and a percentage of $77 \%$ according to media experts and good categories with revisions according to the advice of material experts and media experts.

\section{References}

Wahyudin, 2010. Keefektifan Pembelajaran Berbantuan Multimedia Menggunakan Metode Inkuiri Terbimbing Untuk Meningkatkan Minat dan Pemahaman Siswa. Jurnal Pendidikan Fisika Indonesia, 6: 5862.

Sutarno. 2011. Pengunaan Multimedia Interaktif Pada Pembelajaran Medan Magnet Untuk Meningkatkan Keterampilan Berpikir Generik Sains Mahasiswa. Jurnal Exacta. Vol IX (1), 60-66.

Rante,P. Sudarto. Ihsan, N. 2013. Pengembangan Multimedia Pembelajaran Fisika Berbasis Audio-Video Eksperimen Listrik Dunamis di SMP. Jurnal Pendidikan IPA Indonesia. JPII 2 (2) (2013) 203-208.

Sugiyono. 2017. Metode Penelitian dan \& Pengembangan (Research and Development). Yogyakarta: Alfabeta Bandung.

Alimah, S. 2012. Pengembangan Multimedia Pembelajaran Embriogenesis Hewan Untuk Mengoptimalkan Pemahaman Kognitif Mahasiswa. Jurnal Pendidikan IPA Indonesia. JPII 1 (2) (2012) 131-140.

Nurhayati, F. Syarifah, \& Mutmainnnah. 2014. Penerapan metode demonstrasi berbantu media animasi Software phet terhadap hasil belajar siswa Dalam materi listrik dinamis kelas x Madrasah aliyah negeri 1 pontianak. Jurnal Pendidikan Fisika dan Aplikasinya (JPFA), 4(2): 2087-9946.

Khairunnisak. 2018. Peningkatan Pemahaman Konsep dan Motivasi Belajar Siswa Melalui Simulasi Physic Education Technology (PhET). Jurnal Penelitian Pendidikan IPA (JPPIPA).

Darmawan, D. 2015. Teknologi Pembelajaran. Bandung: Remaja Rosdakarya.

Nurnawati,E. Yulianti,D. Susanto, H. Peningkatan Kerjasama Siswa SMP Melalui Penerapan
Pembelajaran Kooperatif Pendekatan think pair share.) Unnes Physics Education Journal. UPEJ 1 (1) (2012

Hetika. Farida, I. Sari, Y.P. 2017. Think Pair Share (TPS) as Method to Improve Student's Learning Motivation and Learning Achievement. Dinamika Pendidikan 12 (2) (2017) 125-135.

Winarno, dkk. 2009. Teknik Evaluasi Multimedia Pembelajaran. Yogyakarta: Genius Prima Media. 